\title{
VLIV POŽÁRNĚ NEBEZPEČNÉHO PROSTORU NA STAVEBNí ŘíZENí
}

\author{
EFFECT OF FIRE DANGER ZONE FOR CONSTRUCTION MANAGEMENT
}

\author{
Ing. Strnad Mic hal
}

\begin{abstract}
ABSTRAKT
Kolem hořícího objektu vzniká požárně nebezpečný prostor, ve kterém je nebezpečí přenesení požáru sáláním tepla nebo padajícími částmi konstrukcí hořícího objektu. Šiřka požárně nebezpečného prostoru je vymezena odstupovými vzdálenostmi od požárně otevřených ploch požárních úseků hořícího objektu. Požárně nebezpečný prostor nemá zasahovat přes hranici stavebního pozemku kromě veřejného prostranství.
\end{abstract}

Klíčová slova: Požárně nebezpečný prostor, požární ochrana, stavební řízení, územní řízení

\section{ABSTRACT}

Around the building there is a fire burning dangerous area where the risk of fire, radiant heat transfer or falling parts of structures burning building. The width of the fire danger zone is defined odstupovými distances from fire areas open fire compartments of a burning building. Fire danger area does not interfere with building land across the border in addition to the concourse.

Key words: Fire danger zone, fire protection, construction management, land management

\section{VÝVOJ A VLIV PRÁVNÍCH PŘEDPISŮ NA POŽÁRNĚ NEBEZPEČNÝ PROSTOR}

Požárně nebezpečný prostor je posuzován u nevýrobních objektů dle ČSN 730502 již od roku 1976. Do roku 1989 s jeho aplikací nevznikal žádný problém. Zřejmě to je tím, že vlastnické právo soukromých osob bylo potlačováno, rozhodující bylo právo užívací, a lidé si po druhé světové válce zvykli, že „všechno patří všem, tj. státu“ a postavení účastníkủ územních nebo stavebních řízení si tak bylo rovné. $\mathrm{S}$ návratem soukromého vlastnictví začalo narůstat i dogma ničím neomezovaného soukromého zájmu jednotlivce. Co je však dobré pro jednoho člověka, nemusí představovat hodnotu pro někoho jiného. Stavebník nechce vždy totéž, co vlastník nebo uživatel sousedních pozemků a staveb.

Zákon č. 183/2006 Sb., o územním plánování a stavebním řádu, ve znění pozdějších předpisů v $§ 76$ odst. 1 a 2 uvádí: , Umist'ovat stavby nebo zařízení, jejich změny, měnit jejich vliv na využití území, měnit využití území a chránit důležité zájmy v území lze jen na základě územního rozhodnutí nebo územního souhlasu, nestanoví-li zákon jinak. Každý, kdo navrhuje vydání územního rozhodnutí je povinen dbát na soulad s požadavky zvláštních právních předpisů, soulad se stanovisky dotčených orgánů a být šetrný k zájmům vlastníků sousedních pozemků a staveb“. Dále je v § 87 odst. 1 uvedeno: „Stavební úřad oznámí zahájení územního řízení a k projednání žádosti nařídí veřejné ústní jednání, je-li to účelné, spojí jej s ohledáním na místě“. Pro stavební řízení je pak v § 111 stavebního zákona uvedeno, že: „, Stavební úřad přezkoumá podanou žádost, a ověří zejména, zda projektová dokumentace je zpracována $\mathrm{v}$ souladu s podmínkami územního rozhodnutí, a ověř́ rovněž účinky budoucího užívání stavby. Zjistí-li, že projektová dokumentace není v souladu s podmínkami 
územního rozhodnutí, vyzve stavebníka $\mathrm{k}$ odstranění uvedených nedostatků, a stanoví $\mathrm{k}$ tomu přiměřenou lhůtu“. V prováděcí vyhlášce stavebního zákona č. 501/2006 Sb., o obecných požadavcích na využívání území, ve znění pozdějších předpisů, je v $\$ 23$ odst. 2 uvedeno: „, Stavby se umistují tak, aby stavba ani její část nepřesahovala na sousední pozemek. Umístěním stavby nebo změnou stavby na hranici pozemků nebo $\mathrm{v}$ její bezprostřední blízkosti nesmí být znemožněna zástavba sousedního pozemku“ [1]. Podle $\S 2$ odst. 1 písm. b) stavebního zákona, je stavební pozemek definován jako „pozemek, jeho část nebo soubor pozemků, vymezený a určený k umístění stavby územním rozhodnutím anebo regulačním plánem“ a nový pojem zastavěný stavební pozemek jako ,pozemek evidovaný v katastru nemovitostí jako stavební parcela a další pozemkové parcely zpravidla pod společným oplocením, tvořící souvislý celek s obytnými a hospodářskými budovami [2], [5], [6].

Vyhláška č. 137/1998 Sb., o obecných technických požadavcích byla zrušena a nahrazena vyhláškou č. 268/2009 Sb., ve znění vyhlášky č. 20/2012 Sb., která se odkazuje na vyhlášku č. 23/2008 Sb., o technických podmínkách požární ochrany staveb, ve znění vyhlášky č. 268/2011 Sb. V § 11 této vyhlášky je pro stanovení požárně nebezpečného prostoru odkaz na české technické normy. Proto byly tyto požadavky uvedeny do novelizované ČSN 730802 Požární bezpečnost staveb Nevýrobní objekty a ČSN 730804 Požární bezpečnost staveb - Výrobní objekty, kde se uvádí: „Požárně nebezpečný prostor nemá zasahovat přes hranici stavebního pozemku kromě veřejného prostranství (např. do ulice, náměstí, parku, prostoru vodních ploch). Tato úprava odpovídá stanovisku MMR, které uvedlo v komentáŕi stavebního zákona v roce 1998 příklady veřejného prostranství (veřejné komunikace, vodní plochy, parky apod.) jako plochy, na které bylo možné vydat rozhodnutí o povolení výjimky z ustanovení $§ 17$ odst. 5 vyhl. č. 137/1998 Sb., a že pouze pro účely požárně nebezpečného prostoru lze za stavební pozemky považovat ty, které jsou ve vlastnickém nebo jiném právním nároku stavebníka.

Zastavitelnost sousedních pozemků vyplývá z územních plánů obcí, a ověřuje ji příslušný stavební úřad. Podle př́lohy č. 4 k vyhlášce č. 503/2006 Sb., o podrobnější úpravě územního řízení, veřejnoprávní smlouvy a územního opatření, uvede projektant $\mathrm{v}$ dokumentaci $\mathrm{k}$ žádosti o vydání rozhodnutí o umístění stavby charakteristiku území a stavebního pozemku. Z hlediska požární bezpečnosti je třeba tuto charakteristiku uvést i do požárně bezpečnostního řešení tak, aby bylo žrejmé, jaký dopad na sousední pozemky a stavby bude nová stavba resp. požárně nebezpečný prostor mít. Projektantem posuzovaný stavební pozemek musí být vždy vymezen v souladu s ustanovením § 20 odst. 4 vyhlášky č. 501/2006 Sb., o obecných požadavcích na využívání území, ve znění pozdějších předpisů tak, „aby svými vlastnostmi, zejména velikostí, polohou, plošným a prostorovým uspořádáním a základovými poměry umožňoval umístění, realizaci a užívání stavby pro navrhovaný účel a aby byl dopravně napojen na kapacitně vyhovující veřejně prrístupnou komunikaci. Novou právní úpravou byla zrušena možnost vydávání rozhodnutí o výjimce z $§ 17$ odst. 5 vyhlášky č. 137/1998 Sb. stavebním úřadem, ale při správném postupu podle výše uvedených direktiv od roku 1998 došlo pouze k velkému úbytku správních rozhodnutí stavebních úřadů [6].

Podle $§ 114$ stavebního zákona může účastník řízení uplatnit námitky proti projektové dokumentaci, způsobu provádění a užívání stavby nebo požadavkům dotčených orgánů, pokud je jimi přímo dotčeno jeho vlastnické právo nebo právo založené smlouvou, provést stavbu nebo opatření nebo právo odpovídající věcnému břemenu k pozemku nebo stavbě. O námitce, u které nedošlo k dohodě mezi účastníky řízení, stavební úřad rozhodne na základě obecných požadavků na výstavbu, závazných stanovisek dotčených orgánů nebo technických norem, pokud taková námitka nepřesahuje rozsah jeho působnosti. Nedošlo-li k dohodě o námitce občanskoprávní povahy, stavební úřad si o ní učiní úsudek a rozhodne ve věci. Pokud HZS vydá souhlasné stanovisko k projektu, i v případě přesahu požárně nebezpečného prostoru přes hranice pozemku bez řádného odůvodnění, nemá stavební úrad šanci obhájit opačný názor. Pokud zvláštní právní a technická norma něco požaduje, měl by tento požadavek hájit úřad, který byl k tomu účelu zřízen. V praxi vlastník sousedního pozemku není vždy účastníkem 
řízení nebo jsou dokumenty vyvěšeny na úřední desce, a o přesahu požárně nebezpečného prostoru se tak v povolovacím nebo oznamovacím řízení vůbec nedozví. Případný souhlas vlastníka sousedního pozemku, který byl tak hojně využíván v minulosti pro účel povolení výjimky nemá trvalý charakter. Málokterý laik tuší, co požárně nebezpečný prostor ve svém důsledku pro něj jako souseda znamená.

\section{POŽÁRNĚ NEBEZPEČNÝ PROSTOR TYPOVÉHO RODINNÉHO DOMU}

Pro ukázku výpočtu odstupových vzdáleností je použit typový rodinný dům, který je nepodsklepený a má dvě nadzemní podlaží a nevyužívaný půdní prostor. Objekt je téměř obdélníkového tvaru o rozměrech nejdelších stran 11,485 x 9,61 m, kde je hmota ve východním rohu doplněna venkovní terasou. Objekt je zastřešen sedlovou střechou. Hlavní vstup do RD se nachází na jihovýchodní straně, kde se vstupuje přes zádveří do schodištové chodby, z níž jsou přístupné ostatní části RD (obývací pokoj s jídelnou a kuchyní, prádelna, technická místnost a hygienické zázemí se samostatným WC). Na úrovni 2.NP jsou umístěny 3 obytné pokoje, pracovna, šatna a hygienické zázemí.

\section{Požárně nebezpečný prostor je zpracován pro dvě konstrukční řešení:}

- Zděný rodinný dům

- Dřevostavba

V obou konstrukčních řešení bude rodinný dům tvořit jeden samostatný požární úsek.

\subsection{Zděný rodinný dům}

Obvodové a vnitřní nosné stěny RD jsou vyzděny ze systému pórobetonových tvárnic YTONG tl. 375 mm u obvodových stěn a tl. $300 \mathrm{~mm}$ pro vnitřní nosné zdivo. V části terasy tvoří nosnou konstrukci zděný pilî́r rozměru $375 \times 375 \mathrm{~mm}$. Nenosné konstrukce jsou provedeny taktéž jako zděné z tvárnic Ytong. Obvodová konstrukce je zateplena kontaktním zateplovacím systémem z EPS v tl. $220 \mathrm{~mm}$. Stropní konstrukce je provedena stropním systémem YTONG - vložkovým stropem s nadbetonávkou o tl. $50 \mathrm{~mm}$ a následnou aplikací nášlapné vrstvy. Sedlová střecha je vynášena dřevěným krovem vaznicové soustavy, ze spodního líce je konstrukce střechy opatřena SDK podhledem. Střešní krytina je provedena skládaná $\mathrm{z}$ betonové tašky Bramac.

Dle ČSN 730802 čl. 7.2.8 a) se jedná o konstrukční systém nehořlavý a dle ČSN 730833 je rodinný dům hodnocen jako budova skupiny OB1 [3], [4].

Odstupové vzdálenosti samostatně stojícího RD jsou hodnoceny pomocí výpočtu dle hustoty tepelného toku pro jednotlivé požárně otevřené plochy ve fasádách. Hodnocena je vždy největší požárně otevřená plocha v každé fasádě. Konstrukce jsou ve všech částech posuzovány jako požárně uzavřené.

\begin{tabular}{|c|c|c|c|c|c|c|c|c|}
\hline Varianta & Odstup & $\begin{array}{l}\text { Výška } \\
\text { [m] }\end{array}$ & $\begin{array}{l}\text { Délka } \\
\text { [m] }\end{array}$ & $\begin{array}{l}\text { Otevř. } \\
\text { plocha } \\
\text { [m²] }\end{array}$ & $\begin{array}{c}\% \text { otev. } \\
\text { ploch } \\
{[\%]}\end{array}$ & $\begin{array}{c}\text { Zatiž. } \\
p_{\text {vyp }} \\
{[\mathrm{kg} \cdot \mathrm{m} \cdot 2]}\end{array}$ & $\begin{array}{l}\text { Pr.in. } \\
\text { t.toku } \\
{\left[\mathrm{kW} / \mathrm{m}^{2}\right]}\end{array}$ & $\begin{array}{l}\text { Odst. } \\
\text { d } \\
{[\mathrm{m}]}\end{array}$ \\
\hline \multirow[t]{4}{*}{$\begin{array}{l}\text { stavebni objekt hustotou } \\
\text { tep. toku (RD) }\end{array}$} & SEVEROVÝCHODNI & 1 & 0,60 & 0,60 & 100,00 & 40,00 & 101,87 & 0,91 \\
\hline & JIHOVY்CHODNÍ & 2,35 & 1,35 & 3,17 & 100,00 & 40,00 & 101,87 & 2,09 \\
\hline & JIHOZÁPADNÍ & 2,21 & 3,00 & 6,63 & 100,00 & 40,00 & 101,87 & 3,05 \\
\hline & SEVEROZÁPADNÍ & 2,35 & 1,35 & 3,17 & 100,00 & 40,00 & 101,87 & 2,09 \\
\hline
\end{tabular}

Tab. 1 Odstupové vzdálenosti

Požárně nebezpečný prostor od RD nezasahuje do požárně otevřených ploch sousedních objekti̊, což vyhovuje ČSN 73 0802. Objekt sám neleží v požárně nebezpečném prostoru objektů sousedních. 
Porovnáním vypočtených odstupových vzdáleností se situací stavby je možno konstatovat, že požárně nebezpečný prostor od RD nepřesahuje hranici stavebního pozemku investora akce.

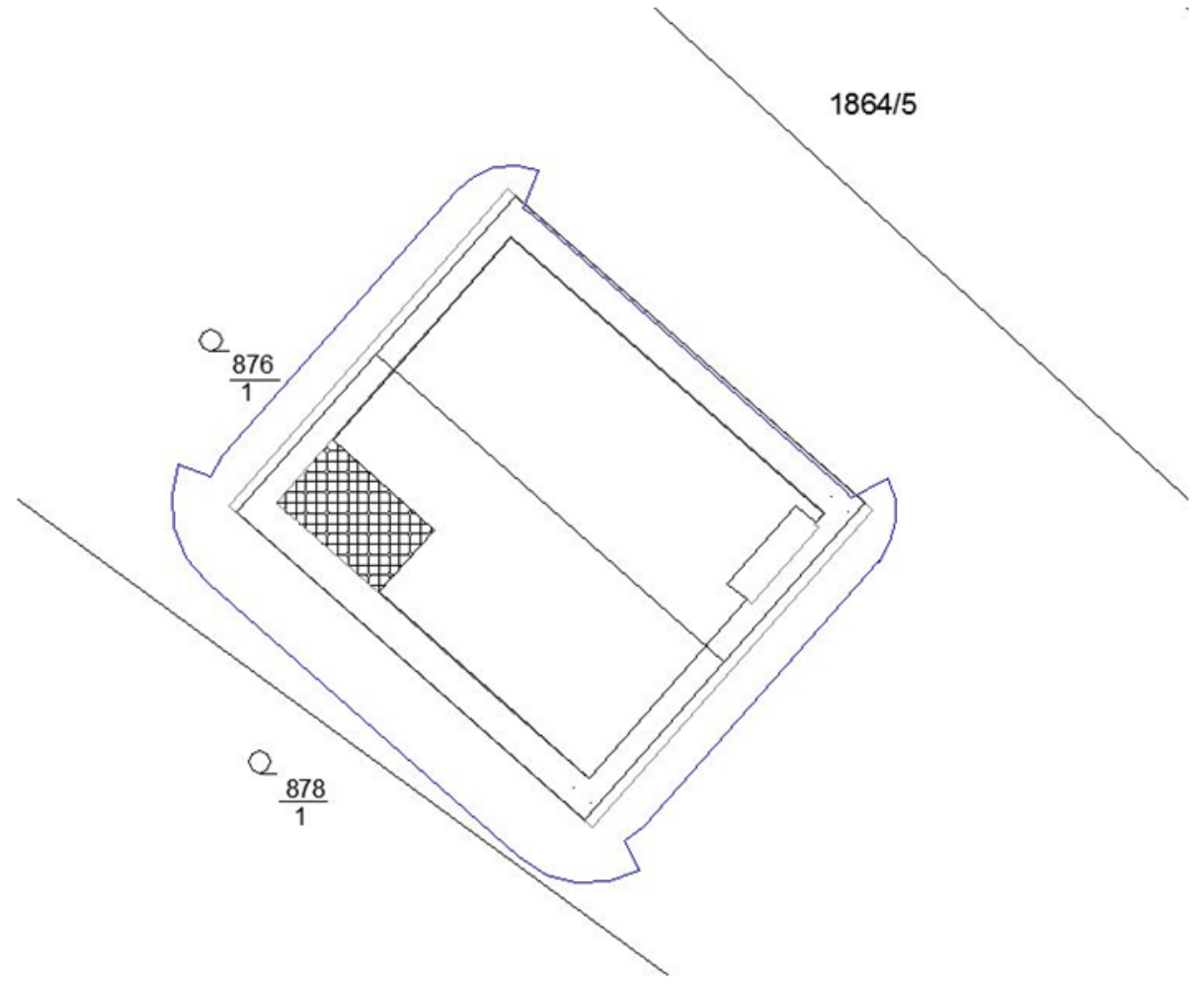

Obr. 1 Požárně nebezpečný prostor zděného rodinného domu

\subsection{Dřevostavba}

Nosné stěny budou provedeny z lehkého rámového systému z dřevěných KVH hranolů, které jsou opláštěné z vnější strany konstrukční deskou Fermacell, z vnitřní strany je konstrukce opatřena SDK deskami. Prostor mezi sloupky je vyplněn izolací ISOVER ISOPHEN. Obvodové stěny jsou zatepleny kontaktním zateplovacím systémem z EPS v tl. 100 mm.

Uvnitř dispozice RD je nosná akumulační stěna tl. $300 \mathrm{~mm}$ mezi obývacím pokojem s kuchyní a chodbou navržena ze železobetonu. V přízemí budou zhotoveny u objektového schodiště ztužující stěny tl. $125 \mathrm{~mm}$ z dřevěných prvků 60/100 mm s opláštěním SDK deskami. Nenosné dělící stěny jsou provedeny ze systému Knauf/Rigips v tl. 100 a tl. $150 \mathrm{~mm}$.

Stropní konstrukce nad 1. NP je tvořena trámovým stropem z dřevěných prvků 100/200 mm, zaklopených OSB deskami $2 \times 25 \mathrm{~mm}$. Střecha je sedlová se sklonem $35^{\circ}$ a se skládanou střešní krytinou z betonových tašek Bramac. Nosnou konstrukci tvoří vaznicový systém.

Dle ČSN 730802 čl. 7.2 .8 c) se jedná o konstrukční systém hořlavý a dle ČSN 730833 je rodinný dům hodnocen jako budova skupiny OB1 [3], [4].

Odstupové vzdálenosti od RD jsou hodnoceny pomocí výpočtu dle hustoty tepelného toku pro jednotlivé požárně otevřené plochy ve fasádách. Hodnocena je vždy největší požárně otevřená plocha v každé fasádě. Obvodové konstrukce rodinného domu jsou v celém rozsahu hodnoceny jako požárně otevřené. 
Odstupy:

\begin{tabular}{|c|c|c|c|c|c|c|c|c|c|}
\hline PU & Varianta & Odstup & $\begin{array}{c}\text { Výška } \\
\text { [m] }\end{array}$ & $\begin{array}{l}\text { Délka } \\
\text { [m] }\end{array}$ & $\begin{array}{l}\text { Otevř. } \\
\text { plocha } \\
{\left[\mathrm{m}^{2}\right]}\end{array}$ & $\begin{array}{c}\% \text { otev. } \\
\text { ploch } \\
\text { [\%] }\end{array}$ & $\begin{array}{c}\text { Zatiž. } \\
\text { p }_{\mathrm{vyp}} \\
{\left[\mathrm{kg}^{-2} \mathrm{~m}^{-2}\right]}\end{array}$ & $\begin{array}{c}\text { Pr.in. } \\
\text { t.toku } \\
{\left[\mathrm{kW} \cdot \mathrm{m}^{-2}\right]}\end{array}$ & $\begin{array}{c}\text { Odst. } \\
\text { d } \\
{[\mathrm{m}]}\end{array}$ \\
\hline \multirow{4}{*}{ RD } & \multirow{4}{*}{$\begin{array}{l}\text { stavebni objekt } \\
\text { hustotou tep. toku }\end{array}$} & SEVEROVÝCHODNI & 4,00 & 11,48 & 45,92 & 100,00 & 55,00 & 119,68 & 8,45 \\
\hline & & JIHOVÝCHODNI & 5,90 & 9,60 & 56,64 & 100,00 & 55,00 & 119,68 & 9,79 \\
\hline & & JIHOZÁPADNI & 4,00 & 7,74 & 30,96 & 100,00 & 55,00 & 119,68 & 7,17 \\
\hline & & SEVEROZÁPADNI & 5,90 & 7,75 & 45,73 & 100,00 & 55,00 & 119,68 & 8,86 \\
\hline
\end{tabular}

Tab. 2 Odstupové vzdálenosti

Požárně nebezpečný prostor od RD nezasahuje do požárně otevřených ploch sousedních objektů, což vyhovuje ČSN 73 0802. Objekt sám neleží v požárně nebezpečném prostoru objektů sousedních.

Porovnáním vypočtených odstupových vzdáleností se situací stavby je možno konstatovat, že požárně nebezpečný prostor od RD přsahuje hranici stavebního pozemku investora akce a to u jihozápadní hranice pozemku parc. č. 878/1, o čemž bude majitel dotčeného pozemku informován.

Dále odstupové vzdálenosti přesahují hranici pozemku investora akce u severovýchodní strany, a to do veřejné komunikace, což je v souladu s ČSN 730802.

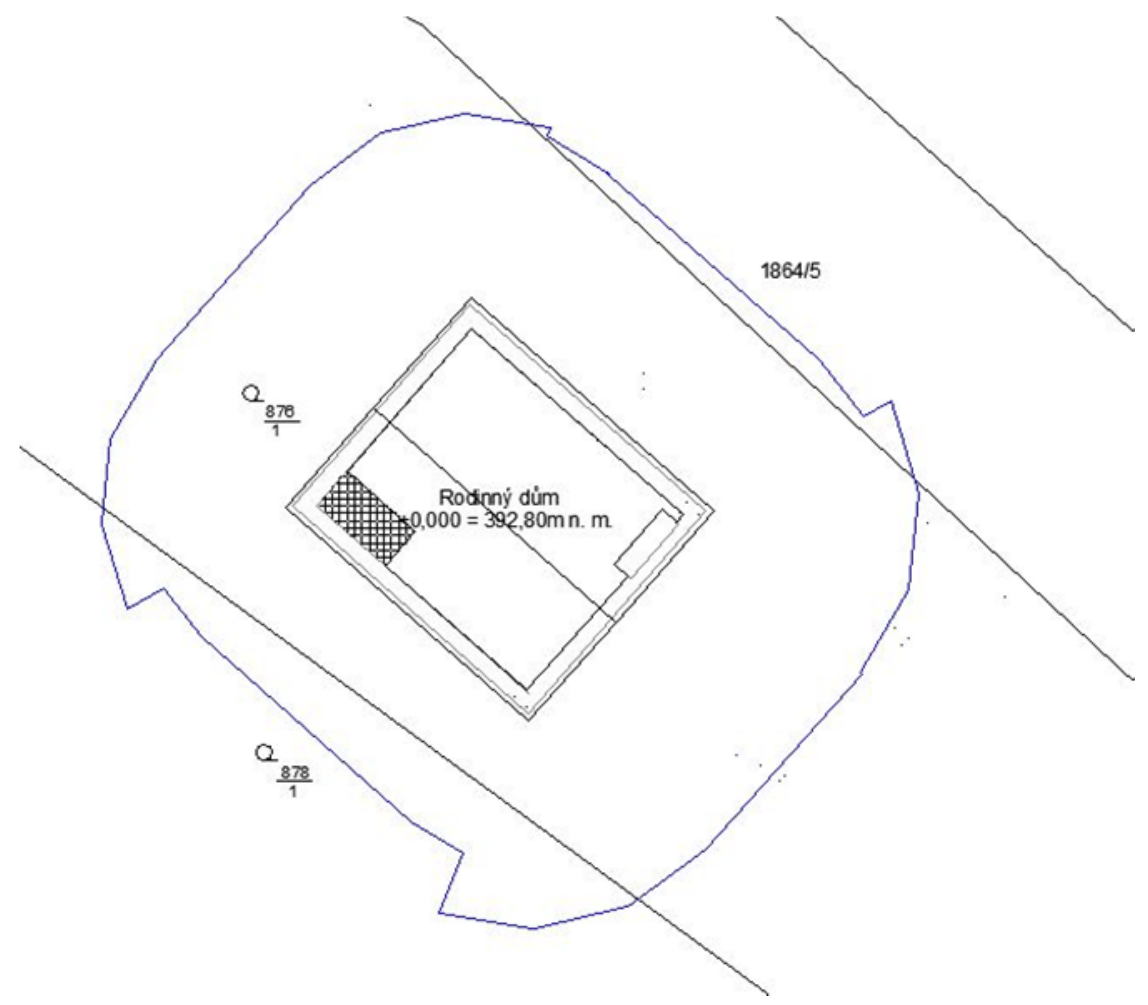

Obr. 2 Požárně nebezpečný prostor dřevostavby

\section{ZÁVĚR}

V př́ípadě konstrukční varianty dřevostavby musí investor informovat majitele sousedního pozemku a požádat o souhlas dotčení požárně nebezpečným prostorem. Pokud by nedošlo $\mathrm{k}$ domluvě potenciálních sousedů, muselo by být požárně bezpečností řešení stavby přepracováno tak, aby navržené materiály odpovídaly při výpočtu dle hustoty tepelného toku odstupové vzdálenosti, která nepřekročí hranici stavebního pozemku investora. Mnohdy musí dojít až k omezení požárně otevřených ploch (oken, ....) v obvodových stěnách, což má neblahý vliv na přirozené osvětlení interiéru. 
Závěrem lze konstatovat, že z výše uvedených důvodů je nutné, aby při umístování stavby byly vzaty v úvahu zde uvedené skutečnosti. Majitelé dvou (popř. více) sousedních pozemků musí vědět o záměrech umístění, respektive výstavby konkrétní stavby a v rámci řízení podle stavebního zákona pak mohou uplatňovat námitky proti záměru $\mathrm{v}$ rozsahu, jakým je jejich právo přímo dotčeno, a to $\mathrm{v}$ souladu s ustanovením § 89 stavebního zákona.

\section{Poděkování}

Tato práce byla podpořena Grantovou agenturou Českého vysokého učení technického v Praze, Grant č SGS15/023/OHK1/1T/11.

\section{Použitá literatura}

[1] Ministerstvo pro místní rozvoj. Vyhláška č. 501/2006 Sb., o obecných požadavcích na využívání území.

[2] Parlament České republiky. Zákon 183/2006 Sb., o územním plánování a stavebním řádu (stavební zákon)

[3] CČSN 730802 - Požární bezpečnost staveb - Nevýrobní objekty.

[4] ČSN 730833 - Požární bezpečnost staveb - Budovy pro bydlení a ubytování

[5] Časopis stavebnictví. Dostupné z: http://www.casopisstavebnictvi.cz/

[6] Technický zpravodaj. Požárně nebezpečný prostor ze všech úhlů pohledu [online]. J.Seidl a spol.,s.r.o., 2012. Dostupné z: http://www.seidl.cz/cz/technicky-zpravodaj/technickyzpravodaj-41/ 